\title{
O TEATRO VAI AO CINEMA: POSIÇÃO SUJEITO
}

\author{
Cássia Peres Martins* \\ Roselene de Fátima Coito** \\ Universidade Estadual do Oeste do Paraná
}

\begin{abstract}
Resumo: Este trabalho tem como objetos de análise a peça teatral Os Sete Gatinhos, escrita em 1958, pelo dramaturgo brasileiro Nelson Rodrigues, e sua adaptação para o cinema, homônima, dirigida por Neville D' Almeida, lançada em 1980. A abordagem teórica que servirá de base para a referida análise será a da Análise do Discurso de orientação francesa, bem como demais teorias que possam contribuir, como as reflexões sobre o sujeito lacaniano de Bruce Fink (1998) e estudos sobre cinema de Ismail Xavier (2008). Fruto de uma pesquisa básica de cunho bibliográfico e interpretativo, o presente trabalho tem como objetivo apresentar reflexões a respeito das posições sujeito, dedicando ainda atenção às personagens a partir da materialidade do texto teatral, observando se estas posições são deslocadas na materialidade fílmica. Verificar-se-á, além desta possibilidade de posições (do) sujeito, a inclusão ou retiradas de diálogos, os sentidos preservados, destituídos ou acrescidos, por meio de elementos que compõem o todo da produção cinematográfica, tais como músicas, cenários, figurinos, constituição da imagem por meio da movimentação da câmera (primeiros e segundos planos, focalização, etc), estratégias que visam à produção de sentidos obedecendo as tendências do cinema dos anos 70/80. Tal reflexão é feita sem deixar de considerar que a materialidade do filme é fruto de uma produção coletiva, comandada por um diretor, havendo responsáveis diferentes para fotografia, cenografia, montagem e trilha sonora, além da intervenção na criação das personagens por cada ator.
\end{abstract}

Palavras-chave: Discurso. Posição sujeito. Materialidade teatral. Materialidade fílmica. Produção de sentidos.

\footnotetext{
* Mestranda em Letras, área de concentração Linguagem e Sociedade pela Universidade Estadual do Oeste do Paraná - UNIOESTE/CAPES.

${ }^{* *}$ Doutora em Estudos Literários, professora do Departamento de Letras da Universidade Estadual de Maringá e da Pós-Graduação - UEM e do Programa de Pós-Graduação Stricto Sensu em Letras da Universidade Estadual do Oeste do Paraná - UNIOESTE.
} 


\section{Introdução}

O Dramaturgo Brasileiro Nelson Rodrigues nasceu na cidade do Recife - PE, em 23 de agosto de 1912, quinto filho de quatorze, do casal Maria Esther Falcão e o jornalista Mario Rodrigues. Em 1916 mudou-se para a cidade do Rio de Janeiro. Quando maior, trabalhou no jornal $A$ Manhã, de propriedade de seu pai. Foi repórter policial durante anos, de onde acumulou uma vasta experiência para escrever suas peças a respeito da sociedade.

Escreve sua primeira peça teatral em meados de 1941, A Mulher sem pecado, a qual não teve repercussão nenhuma perante o público; apenas alguns críticos e amigos elogiaram. O sucesso viria mesmo com Vestido de Noiva, em 1943, que trazia, em matéria de teatro, uma renovação nunca vista em nossos palcos. Apesar de suas peças serem taxadas muitas vezes como obscenas e imorais, a consagração surge com vários outros sucessos, transformando-o no grande representante da literatura teatral de seu tempo. Escreveu também crônicas e contos que se tornaram famosos. Faleceu na manhã do dia 21 de dezembro de 1980, um domingo.

Neste trabalho voltaremos nossa atenção para a materialidade do texto teatral Os Sete Gatinhos, cuja estréia de sua primeira montagem ocorreu em 17 de outubro de 1958, no Teatro Carlos Gomes, Rio de Janeiro, sob a direção de Willy Keller, e para a materialidade fílmica produzida com o mesmo título, lançada em 1980, sob a direção de Neville D' Almeida

Os Sete Gatinhos, classificada por Sábato Magaldi ${ }^{1}$, sob a orientação do próprio Nelson Rodrigues, como uma de suas Tragédias Cariocas, conta a história da família de "seu" Noronha, um contínuo da Câmara de Deputados que mora no Grajaú, bairro da zona norte da cidade do Rio de Janeiro, com a mulher, D. Aracy, e suas filhas Aurora, Hilda, Débora, Arlete e Silene, de apenas 16 anos. As quatro filhas mais velhas oferecem favores sexuais para garantir os estudos e o enxoval para o casamento da mais jovem, Silene, a única virgem, que estuda num colégio interno e que é olhada como a esperança para salvar a honra da família. A vida da família toma um rumo diferente, quando a garota é trazida do colégio por Dr. Portela que a acusa de matar a pauladas uma gata grávida, que depois de morta dá a luz a sete gatinhos vivos e saudáveis. A partir do incidente ocorrido na escola, descobre-se que a jovem já não é mais "pura", pois está grávida, justificando no texto a atitude de matar a gata prenha, como um momento de raiva ou inconformismo com ela mesma.

No primeiro ato, o único a se passar fora da casa da Família Noronha, o leitor é apresentado ao personagem chave responsável pelo desencadeamento de toda trama: Bibelot,

\footnotetext{
${ }^{1}$ Crítico teatral, teatrólogo, jornalista, professor, ensaísta e historiador brasileiro.
} 
um homem que dá sorte com as mulheres, está sempre de terno branco e carrega um revólver porque uma vez lhe disseram que seria assassinado por uma prostituta. Apresentado como um possível cliente de Aurora, a filha mais velha, é o homem por quem ela se apaixona e com o qual passa a se relacionar, mesmo sabendo que ele também mantém um relacionamento amoroso com uma jovem de 16 anos e é casado com uma mulher doente, à beira da morte.

Aurora, a única que ficou ao lado de Silene, enfrentando o restante da família em sua defesa, assegura ao pai que, atendendo a um pedido seu, Bibelot mataria o responsável pela gravidez de Silene. No entanto, ao tentar descobrir quem desgraçara a honra da irmã caçula, se dá conta que o pai do filho de Silene é o próprio Bibelot.

Os acontecimentos finais da peça são movidos por uma busca, baseada em uma espécie de profecia, procura-se o "homem vestido de virgem que chora por um olho só" que, segundo a profecia, seria o responsável pela perdição das filhas de "seu" Noronha. E em um dado momento tudo leva a crer que este homem trata-se de Bibelot, que consequentemente é assassinado por "seu" Noronha. No entanto, ele não chora apenas uma lágrima, seus dois olhos choram, as filhas se voltam contra "seu" Noronha, constatando que ele é o único responsável pela destruição do seio familiar que ele próprio construiu, que em seu desespero chora apenas uma lágrima; são as próprias filhas que acabam com a vida dele.

O cineasta brasileiro Neville Duarte de Almeida, nasceu em Belo Horizonte - MG, em 1941. Em 1958, sai dos bancos das igrejas metodistas para o Centro de Estudos Cinematográficos de Belo Horizonte, onde conviveu com os melhores críticos do cinema da época. Influenciado por sua vivência em Nova York e Londres, onde morou nos anos 60 e 70, dirigiu filmes censurados pela ditadura militar e nunca exibidos, como Mangue bang (1971, Surucucu catiripapo (1971) e Gatos da noite $(1973)^{2}$. Sua carreira abrange ainda desde filmes experimentais, como Jardim de Guerra (1968), seu longa metragem de estréia, até campeões de público, como A dama do lotação (1975), a terceira maior bilheteria do cinema nacional até a atualidade. Sem abandonar seu lado experimental dirigiu também Rio Babilonia (1985), Navalha na carne (1997), bem como o remake de Matou a família e foi ao cinema (1990). Desenvolveu um cinema que mistura marginalidade e fantasias eróticas, como em $A$ dama do lotação e Os sete Gatinhos (1980), dois textos do dramaturgo Nelson Rodrigues.

\footnotetext{
${ }^{2}$ As datas de produção e lançamento dos filmes são imprecisas, variam de uma fonte de informação para outra; utilizamos as datas que mais se repetem. Em alguns sites que exibem reportagens ou mesmo depoimentos, afirmam que os filmes censurados de Neville D' Almeida não foram exibidos em circuito no Brasil. $\mathrm{O}$ filme Mangue Bangue, por exemplo, teria se perdido do próprio diretor, permanecendo arquivado no Museu de Arte Moderna de Manhattan, Nova York, onde teria sido exibido uma única vez em 1973. Frederico Coelho (2012) afirma ter encontrado o filme, durante uma pesquisa em 2006.
} 
Os Sete Gatinhos é produzido em finais dos anos 70, período em que sob o controle do governo militar, a Embrafilme garante espaço para os filmes nacionais, em meio ao domínio dos filmes estrangeiros, com financiamento público e salas de exibição garantidas em lei. Era comum a produção de filmes de baixo orçamento, com forte apelo erótico, conhecidos como Pornochanchadas.

A pornochanchada estava no verdadeiro do dizer cinematográfico da época. $\mathrm{Na}$ produção em questão ela acaba por mascarar os questionamentos mais profundos da obra original. Num país que sofria com a censura imposta pelo militarismo, os cineastas deviam "dançar conforme a música", retratando problemas sociais pelo viés da comédia e do erotismo, um certo dizer sem querer dizer, pensar sem fazer pensar: elementos a serem considerados ao refletirmos sobre as condições de produção desse dizer, presente na materialidade fílmica em análise.

Carlos Diegues, cineasta brasileiro, menciona em entrevista concedida ao O Estado de São Paulo, em 31 de agosto de 1978 o seguinte:

\begin{abstract}
Um negócio que eu também acho muito grave é essa espécie de patrulha que existe no Brasil. Uma espécie de polícia ideológica que fica te vigiando nas estradas da criação, para ver se você passou da velocidade permitida. São patrulheiros que ficam policiando permanentemente a criação, a criatividade, tentando limitar ou dirigir para essa ou aquela tendência. [...] a gente tem que reagir, porque senão vai ficar mais grave. Vai chegar um momento em que, antes de começar o filme, você vai ter o certificado da Censura, o certificado do Concine e o certificado das patrulhas ideológicas. (DIEGUES, 1988, p. 33-36)
\end{abstract}

Segundo Ruy Gardnier, a visão predominante que se tem hoje da obra de Nelson Rodrigues resulta principalmente dos filmes e episódios televisivos, nela baseados, definida por clichês como "a peculiaridade da vida do subúrbio carioca, assemelhada à comédia de costumes e esvaziada de dramas tabus, vividos quase como um jogo farsesco de opereta" (GARDNIER, 2010), ou ainda durante os anos 70, a partir dos filmes de Neville D' Almeida, propagava-se a seguinte definição da obra de Rodrigues: "escracho das situações dramáticas, o sexo como instância liberadora e os flertes confessos com a pornografia" (GARDNIER, 2010). A respeito da produção cinematográfica de Neville D’ Almeida, Gardnier ainda afirma que:

\footnotetext{
A iconoclastia presente nas situações criadas persiste mesmo que simplificada pelo exagero da mise-en-scène, e abre o campo para um questionamento que está no coração da obra de Nelson: as paixões irredutíveis da carne contra os códigos de conduta social e familiar. A maneira de colocar a questão é diferente em Nelson e Neville, mas a questão parece bem a mesma.

Ver Os sete gatinhos como um filme trash ou uma simples comédia deselegante impede que se perceba toda a importância desse filme. [...] Os sete gatinhos só
} 
adquire grandeza quando levado a sério, quando o escracho é compreendido não como uma instância humorística, mas como uma posição existencial diante de um mundo que está sendo encenado. (GARDNIER, 2010)

Os diálogos do texto fonte são conservados em sua maioria no filme, utilizando a estratégia própria da produção cinematográfica de intercalar as cenas, a fim de produzir o sentido de que podem estar acontecendo concomitantemente, sem interferir no desenrolar da trama. As cenas são montadas no clima cômico da Pornochanchada. Para garantir este clima, Neville D' Almeida abre mão das cenas nas quais a religião espírita ganha peso no desencadear da trama, manifestando-se por meio da mediunidade da filha Hilda que recebe o espírito de primo Alípio, conforme este trecho do início do terceiro ato:

HILDA (com voz masculina e ofegante) - Velho assassino!

"SEU” NORONHA (na sua humildade) - Irmão, esse homem ofendeu minha moral! Desgraçou minhas filhas!

HILDA - Tuas filhas são umas sem-vergonhas! Vivem pegando homem!

"SEU" NORONHA (sôfrego) - Mas o homem chora por um olho só!

HILDA - Você está marcado!

"SEU" NORONHA - O homem tem uma lágrima só?

HILDA - Olha que você pode morrer!

"SEU" NORONHA - E como eu vou conhecer esse homem? Saber quem é ele? Judeu? Como é ele?

HILDA - O homem goza chorando, chora morrendo!

"SEU" NORONHA (repetindo com angústia) - Goza chorando, chora morrendo... (num apelo) mas ele vem aqui e quando?

HILDA - O homem vestido de virgem!

"SEU" NORONHA - Vestido de virgem!

HILDA - Você enterra no quintal, o homem e a lágrima! Vocês ajudem a carregar o corpo ... (para"seu" Noronha) E você enterra a faca no coração!

"SEU" NORONHA - Mas eu queria apunhalar o olhar da lágrima!

HILDA - Deixa o homem dormir e enterra a faca no coração! (RODRIGUES, 2004, p. 172-173)

Estes diálogos em que primo Alípio fala por meio da voz de Hilda, não são conservados no filme, esta espécie de oráculo que dita uma profecia, assim como nas tragédias gregas; é mantido no filme apenas pelas falas de "seu" Noronha, que relata sua conversa com o espírito do Dr. Barbosa Coutinho no espelho:

"SEU" NORONHA (sem ouvi-la) - Agora vem o importante. Eu sempre senti que as meninas, aqui, eram marcadas e, ontem, eu finalmente soube por que vocês são umas perdidas! Isto é, soube de fonte limpa, batata! Quem me explicou tudinho (enfático) não mente!

D. ARACY - E quem é ele?

"SEU" NORONHA (triunfante) - O dr. Barbosa Coutinho! (toma respiração) O dr. Barbosa Coutinho, que morreu em 1872, é um espírito de luz! Foi médico de d. Pedro II e o melhor vocês não sabem: os versos de d. Pedro II não são de d. Pedro II. Quem escreveu a maioria foi o dr. Barbosa Coutinho. D. Pedro II apenas assinava. (triunfante) Perceberam?

(Arlete faz um gesto a significar que o pai está maluco.)

"SEU" NORONHA - Vão ouvindo! (muda de tom) Eu sempre senti que havia alguém atrás de minha família, dia e noite. Alguém perdendo as nossas virgens! E 
como eu ia dizendo, ontem, o dr. Barbosa Coutinho me confirmou que existe, sim, este alguém. Alguém que muda de cara e de nome. Pode ser um rapaz bonito ou, então, um velho como o "seu" Saul.

ARLETE - Ora, papai, o senhor acredita nesses troços!

"SEU" NORONHA - Quero te dizer só uma coisa Arlete: você é assim mal criada comigo, sabe por quê? Porque é um médium que ainda não se desenvolveu. (taxativo) Você se desenvolva, Arlete, ou seu fím será triste... E chega, ouviu? Chega! (novo tom) E, então, o dr. Barbosa Coutinho mandou que eu olhasse no espelho antigo. (arquejante) Pois bem. Olhei no grande espelho e vi dois olhos, vejam bem, dois olhos, um que pisca normalmente e outro maior e parado. (com súbita violência) $\mathrm{O}$ pior é que só o olho maior chora e o outro, não. [...] Esse alguém, que chora por um olho só, sabe que ainda temos uma virgem! (RODRIGUES, 2004, p. 150)

Na materialidade fílmica são acrescentadas cenas cômicas com apelo erótico, que não se apresentam na materialidade teatral, como a cena do encontro acertado por "Seu" Noronha, entre sua filha Arlete e o Deputado, a moça corre nua e mergulha em uma piscina, encenando uma brincadeira de gato e rato com o outro personagem. Mesmo tom de brincadeira erótica toma a cena em que Débora vai à loja de seu Saul para dar um telefonema; a música no lugar das falas garante o efeito cômico da cena de um "velho" acariciando uma jovem, cena que no texto teatral é apenas relatada vagamente por Débora a sua mãe D. Aracy, sem detalhes eróticos.

D. Aracy é chamada de "gorda" pelo marido, que há tempos não a procura sexualmente, é ela que se distrai fazendo desenhos obscenos no banheiro. $\mathrm{O}$ ato de desenhar também é mostrado no filme, feitos com batom vermelho no azulejo branco do banheiro. $\mathrm{O}$ que justificou a frase que ficou famosa, pronunciada pelo personagem do "Seu" Noronha, no filme, após ter visto os desenhos: "Eu quero saber quem foi que desenhou "caralhinhos" voadores na parede do banheiro". Esta atitude é justificada mais tarde, pela solidão que sente D. Aracy e a falta que lhe faz as relações sexuais, fato enfatizado pela prática da masturbação pela personagem.

Desta maneira sem deixar de contar uma tragédia, a história vai vestindo a máscara da comédia erótica, re-significando o texto fonte.

\section{Da materialidade teatral à materialidade fílmica}

Uma vez que o intuito do presente trabalho é também refletir sobre as posições sujeito ocupadas pelas personagens do texto teatral e se há algum deslocamento destas posições no filme, não se deve deixar de considerar que são personagens de fícção, personagens descritos por um autor, originariamente escritos no papel, existentes na 
materialidade do texto teatral no mundo das palavras, na materialidade fílmica no mundo das imagens e sons, com o objetivo de representar pessoas, já como constatava Beth Brait, a partir dos dizeres de Ducrot e Todorov:

Uma leitura ingênua dos livros de ficção confunde personagens e pessoas. Chegaram
mesmo a escrever "biografias" de personagens, explorando partes de sua vida
ausente do livro ("o que fazia Hamlet durante seus anos de estudo?"). Esquece-se
que o problema da personagem é antes de tudo lingüístico, que não existe fora das
palavras, que a personagem é "um ser de papel". Entretanto recusar toda relação
entre personagem e pessoa seria absurdo: as personagens representam pessoas,
segundo modalidades próprias da ficção. (DUCROT; TODOROV apud BRAIT,
1985, p. 10-11)

Nelson Rodrigues é um nome de grande significância da literatura dramática brasileira, trabalhou muito tempo como repórter, escrevendo para páginas policiais, considerase possível que muito de suas tragédias tenham origem na criminalidade que noticiava, daí porque o ambiente de suas tragédias cariocas se dariam nas regiões mais pobres do Rio de Janeiro, seus personagens suburbanos. Ora não seria tentador, para uma imaginação fértil, a história de um pai que é assassinado pelas próprias filhas? Que família seria esta? Que filhas são estas? Que espécie de pai é digno de ser morto desta maneira? A resposta seria a nossa família Noronha.

Personagens representam pessoas que poderiam existir, reflexos da pessoa humana, que obedecem às leis particulares que regem o texto, condições para sua existência. Brait já aponta para a existência deste conceito na mimese aristotélica. Segundo a pesquisadora durante muito tempo mimeses era traduzida como somente imitação do real, no entanto, “Aristóteles estava preocupado não só com aquilo que é 'imitado' ou 'refletido' num poema, mas também com a própria maneira de ser do poema e com os meios utilizados pelo poeta para a elaboração de sua obra" (BRAIT, 1985, p. 30).

Já, o sujeito, para os analistas do discurso de orientação francesa, é constituído a partir da linguagem, ou seja, é um individuo que se torna sujeito pela interpelação ideológica, pois ao nascer, o mundo, representado simbolicamente pela/na linguagem, já está posto e o que prevalecerá em sua constituição é a vontade do outro, o outro que lhe é imposto pela linguagem, desde os primeiros contatos humanos, pais, avós e irmãos. No entanto, este não tem consciência do que lhe constitui, segue fazendo escolhas julgando-se pleno e dono de si.

O autor não escapa a esta regra, pois antes de se propor a produzir uma unidade textual e organizar seu sentido, constituiu-se em sujeito. Mas como defini-lo então, uma vez que a produção artística lhe confere o status de estar no controle? Trata-se de um sujeito que se julga capaz de criar o novo e seus leitores e espectadores também acreditam nisso. Um 
sujeito capaz de deixar sua marca, seu estilo marcado em sua obra, trata-se da marca de uma subjetividade que produziu determinado texto no como fazê-lo, o que já merecia atenção desde Aristóteles, como mencionado anteriormente.

Este sujeito autor de que estamos falando trata-se de uma individualidade posta em um tempo e espaço definidos historicamente, que se propõe a representar uma realidade, "com consciência do que está fazendo, mas sem o domínio de todas as alternativas postas por essa mesma realidade" (MAGALHÃES, 2003, p. 76)

Michel Pêcheux, filósofo francês e analista do discurso, explica esta consciência que o sujeito supõe ter, por meio do que chama de esquecimentos. Segundo o teórico, são dois os tipos de esquecimentos que sofre o sujeito; o esquecimento número um e o número dois.

Para Pêcheux (1997), o esquecimento número um é o esquecimento ideológico, é este que nos dá a sensação de sermos a origem do que dizemos, no entanto, apenas retomamos sentidos que já existem. Este esquecimento acontece inconscientemente e resulta do modo pelo qual a ideologia nos afeta, causa a impressão de que as palavras significam exatamente o que queremos. "Na realidade, embora se realizem em nós, os sentidos apenas se representam como originando-se em nós: eles são determinados pela maneira como nos inscrevemos na língua e na história e é por isto que significam e não pela nossa vontade" (ORLANDI, 2007, p.35).

Já o esquecimento número dois é da ordem da enunciação. Funda-se no fato de que o autor de determinado enunciado escolhe a melhor maneira de se fazer claro, produz a sensação de realidade do pensamento, tem-se a impressão de que o que está dito só poder ser dito com aquelas palavras e não com outras. Trata-se de um esquecimento parcial, semiconsciente, ou seja, escolhemos as palavras para dizer o que queremos, mas não temos o controle sobre o leque de palavras que nos é oferecido. Este leque depende da formação discursiva na qual nos inscrevemos; depende como a história e a ideologia nos interpela.

Segundo Magalhães, a teoria a respeito do esquecimento número dois é um dos apontamentos importantes para refletirmos sobre autoria, ou função autor exercida pelo sujeito, com mais tranquilidade, pois por meio deste conceito, Pêcheux trabalha o desejo e a possibilidade de a subjetividade controlar o sentido do discurso. "O sujeito busca o controle de seu dizer, sendo aí instalada a possibilidade de criação do novo" (MAGALHÃES, 2003, p. 84). Mas isto não significa que o resultado não esteja atravessado pelas determinações inconscientes. Apenas aponta para a possibilidade de reconhecermos marcas de uma 
subjetividade, por meio de suas escolhas lexicais ou estilísticas, por meio da maneira pela qual esta subjetividade organiza os sentidos e re-significa o que já foi dito, marcas de autoria.

O cineasta também passa pelo mesmo processo, ao falar da estética de Umberto Barbaro $^{3}$, Ismail Xavier, em seus estudos sobre o discurso cinematográfico, descreve a arte realista como resultado de um processo complexo:

\begin{abstract}
de um lado, há o projeto consciente do artista, tendente a buscar um realismo definido dentro dos limites de sua visão de mundo; de outro, há o trabalho efetivo de produção, onde a imaginação opera trazendo consigo os imperativos de tal comando consciente e outras determinações que escapam à consciência do artista (condições impostas pelo meio de representação, a incidência da história). (XAVIER, 2008, p. 58)
\end{abstract}

Em síntese, ao falarmos sobre personagens, devemos considerá-los como instâncias discursivas organizadas para produzir efeito de realidade, de acordo com o que seu autor, diante do que o mundo lhe oferece, toma como realidade, ou traduziria como possibilidade de realidade, a verossimilhança artística.

Ao tomarmos um sentido da máxima de Lacan, traduzida por Bruce Fink: “ 'O desejo do homem é que o Outro o deseje' ou 'O homem deseja o desejo do Outro por ele'. A causa de seu desejo pode tomar a forma da voz de alguém ou de um olhar que alguém lhe dirija". (FINK, 1998, p. 82). Podemos inferir que no caso de um sujeito que se propõe a escrever dramaturgia, exercendo a função de autor, um de seus principais desejos, visto que está produzindo uma espécie de produto a ser ofertado para uma platéia, é que os espectadores desejem sua história. De certa maneira um texto teatral trata-se de um discurso a ser consumido: como literatura, visando cativar leitores; como possibilidade de dramatização, visando chamar atenção dos diretores de teatro, e por fim visando agradar a platéia. Este desejo também se aplica aos diretores de cinema, produtores, e demais profissionais envolvidos, cujo maior desejo é cativar o público. Este desejo é muito nítido em Os Sete Gatinhos de Neville D' Almeida, preso ao que trazia grandes bilheterias na época, o erotismo.

No entanto, não poderia ser qualquer erotismo, é preciso um erotismo comercial, que passe pela censura, e que seja rodrigueano. Um Nelson Rodrigues revisado, repaginado, direto dos anos 50 aos finais dos anos 70. É preciso que este erotismo case com a obra de Rodrigues e com a identidade que vem sendo construída deste autor ao longo dos anos, mesmo que esta identidade seja firmada através das adaptações para o cinema e televisão. Há quem diga que Neville D’Almeida não conseguiu captar a obra de Rodrigues a contento, a exemplo temos a

\footnotetext{
${ }^{3}$ Umberto Barbaro foi um crítico de cinema italiano e ensaísta. Ele nasceu em Acireale em 03 de janeiro de 1902 e morreu em 19 de março de 1959 em Roma.
} 
crítica da época sobre Os Sete gatinhos, o crítico Rubens Edwald Filho, publicou no $O$ Estado de São Paulo, em 23 de abril de 1980, o seguinte:

o novo filme de Neville é um desastre total. O erro básico é principalmente uma questão de tom. Apesar de seu diálogo brilhante, Nelson não é realista, seus personagens são arquétipos, maiores que a vida, figuras empostadas de um universo trágico muito particular do autor. Quem compreendeu muito bem isso foi Arnaldo Jabor nas suas melhores fitas baseadas em sua obra: "Toda Nudez Será Castigada" e principalmente "O Casamento".

Mas Neville reduz tudo à simples comédia de costumes, partindo para um realismo crítico que não funciona nunca. Ele não soube captar aquilo que no próprio "pressrelease", Nelson chama de "absurda família de classe média". Ficou apenas na superfície, no folclore, no histerismo. (EDWALD FILHO, 2013)

Todavia, houve opiniões diferentes na época, o crítico Moura Reis, afirmou em 24 de abril de 1980, no Jornal da Tarde:

Este filme - que iniciou sua trilha de escândalo quando, no recente festival de Gramado, despertou a ira do secretário da Cultura do Rio Grande do Sul - é surpreendentemente correto. Certamente a melhor incursão do cinema no mundo mórbido e delirante de Nelson Rodrigues criou ao distorcer, de forma muito pessoal, o que seria a realidade dos subúrbios da Zona Norte Carioca vista pelos chamados jornais populares. Excessivamente violento - sobretudo a violência verbal - embora não chegue sequer próximo ao "filme que nasceu com a predestinação das obrasprimas" como, no seu exagero peculiar, o próprio Nelson Rodrigues o descreveu, é bem feito, apesar de excessivamente apegado à origem teatral, o surpreende pela correção com que capta os desvarios do escritor. (REIS, 2013)

Importante é que ainda que seja Nelson, será também Neville D’ Almeida; será Nelson aos olhos de Neville, de acordo com as condições de produção da época. Trata-se de Neville, assumindo a função de autor, re-significando o discurso de Nelson, destacando sentidos e produzindo novos sentidos. Por meio de sua interpretação do que seria o discurso rodrigueano, contribui para a constituição do discurso proferido a respeito do dramaturgo, a respeito de quem é Nelson Rodrigues na história da dramaturgia brasileira. E mesmo que muitos acreditem que a produção cinematográfica baseada na obra de Nelson Rodrigues acaba por deturpar os sentidos produzidos pelo dramaturgo, mesmo que o filme Os Sete Gatinhos venha despistar os temas centrais e importantes do texto fonte, o procedimento adotado foi acompanhado pelo próprio dramaturgo, que frequentou as filmagens de forma participativa como afirma a atriz Sura Berditchevsky, que interpretou a personagem Hilda no filme:

Entre uma novela e outra, eu fui fazer o primeiro filme de Nelson Rodrigues "Os Sete Gatinhos", que foi quando eu o conheci pessoalmente, eu não me lembro muito bem se foi em 78 ou 79. Nós filmávamos na Cinédia. E foi maravilhoso, apesar de que eu não gostei do filme. Foi um contato super interessante. Ele ia a todas as filmagens [...] Ele era participativo, queria acompanhar tudo, mas também fícava muito cansado, porque era cansativo. (BERDITCHEVSKY, 2013) 


\section{Personagens que vão do teatro para o cinema}

A proposta é de uma reflexão sobre as posições sujeito que as principais personagens da trama em questão ocupam. Para que não nos estendamos muito, considerando a brevidade deste gênero discursivo a que nos dispusemos a produzir, reportemos nossa atenção para duas cenas marcantes e decisivas do enredo, ambas conservadas na materialidade fílmica. A primeira delas, que acontece logo após a confirmação da gravidez de Silene, possui as seguintes falas:

HILDA - Não te mete nisso, papai! (muda de tom) Ah, quer saber, pois não! Vou para Santos porque uma colega minha fez, em Santos, num mês, só num mês, 170 contos. Agora que eu sei que Maninha é igual a nós, ou pior...

"SEU" NORONHA (gritando) - Pior!

ARLETE - Pois é. Eu não fico mais aqui! Não quero mais ficar!

"SEU" NORONHA - (num outro berro) - Espera! Tenho outra idéia! Ninguém precisa sair daqui! Venha o senhor também, dr. Bordalo!

DR. BORDALO - Mas não há motivo! Não há motivo!

"SEU" NORONHA - (frenético) - Ouçam a idéia. (baixando a voz, carinhoso, ignóbil) Eu não vou voltar mais a Câmara, não senhor, e por que? Ah, não! Vou ficar em casa, porque o que vocês ganhariam, lá fora, vão ganhar aqui, aqui!

DR. BORDALO - (para todos) - Este homem está louco!

"SEU NORONHA" - (num desafio feroz) - Por que louco? Vamos, explique!

DR. BORDALO - O senhor está propondo um bordel de filhas!

"SEU" NORONHA - Por que não? Olha: eu não vou mais servir cafezinho, nem água gelada, a deputado nenhum! (para as filhas) Vocês também podem largar o emprego! (para o médico, num riso sórdido) $\mathrm{O}$ emprego de minhas filhas é uma mascara! (corta o riso) Tive outra idéia: (cara a cara com o médico) o senhor quer começar? Quer ser o primeiro?

DR. BORDALO - (recuando) - O que é que o senhor quer insinuar?

"SEU" NORONHA - Eu sei que o senhor é metido a santo: faz de graça parto de negra, não cobra consulta, mas insisto, (aponta para as filhas) escolha: qualquer uma, escolha! (agarra a filha menor)

AURORA - (gritando) - Não, papai!

("Seu" Noronha atira Silene no chão, aos pés do médico.)

SILENE - (num apelo, com as duas mãos em cima do ventre) - Não quero!

DR. BORDALO (ajudando-a) - Levante-se!

"SEU" NORONHA (possesso para ela) - Ou tu vais com ele ou acabo com a tua gravidez a pontapés! (para os outros) Se foi de um, pode ser de todos!

AURORA - (histericamente) - Eu vou no lugar de Maninha!

"SEU" NORONHA - Quero Silene!

DR. BORDALO (fora de si, para as outras) - E vocês? Não dizem nada? Não reagem? Nem a senhora, que é mãe? (gritando) Por que não fogem? Fujam! Abandonem esta casa! (apontando "seu” Noronha) Este homem é louco! (para as mais velhas) Eu recebo vocês na minha casa! Ficam lá, até que...

"SEU" NORONHA (triunfante) - Viu? (apontando Aurora) Só esta bestalhona quis protestar. As outras espiam e calam ...A porta está aberta e ficam!

DR. BORDALO (furioso) - Vocês têm uma alma e... (estaca, atônico) Ou não têm alma?... (como e pensasse em voz alta) Mas se não fogem é porque são escravos, uns dos outros...

"SEU" NORONHA (exultante) - Nem elas se livram de mim, nem eu me livro delas! (para Silene) Você vai ou não vai aqui com o doutor?

AURORA (soluçando) - Maninha, não, papai! 
SILENE (para Aurora) - Obrigada, Aurora... (transida para o pai) Vou. (RODRIGUES, 2004, p. 168)

Ao longo da narrativa podemos definir as personagens das filhas como fruto do desejo do pai, o que nos lembra as reflexões sobre sujeito de Lacan, entendendo que o homem se constitui em sujeito por meio do desejo do outro. No entanto, não se pode esquecer que estamos falando de personagens de ficção, dotados sim de desejos, desejos impostos pelo autor de seus discursos, que no anseio de produzir um discurso desejável, transfere aos seus personagens os desejos de sua platéia, a burguesia carioca, na qual também está inserido. Mais tarde, por meio do cinema, esta platéia é bem maior, mas não deixa de ser a sociedade regida pelos preceitos morais, impostos pelas instituições da Família, Igreja, Escola e Estado.

"Seu” Noronha é o anti-herói fracassado, condenado por seus próprios erros, não se conforma com sua condição de pobreza, não se conforma com sua função de contínuo na câmara dos deputados, se sentindo humilhado em ter que servi-los, sua busca incansável por corrigir sua condição social o leva a uma sucessão de enganos que contribuem para o apodrecimento ao qual sua família está fadada.

Mas isto não o destitui da posição de chefe da família, o patriarca absoluto frente uma família só de filhas, filhas que não se casam, fato que também lhe desperta revolta. Ao refletir sobre a sociedade androcêntrica, observando a sociedade cabila no início dos anos sessenta, Bourdieu relata:

\begin{abstract}
O principio da inferioridade e da exclusão da mulher, que o sistema mítico-ritual ratifica e amplia, a ponto de fazer dele o princípio de divisão de todo o universo, não é mais que dissimetria fundamental, a do sujeito e do objeto, do agente e do instrumento, instaurada entre homem e a mulher no terreno das trocas simbólicas, das relações de produção e reprodução do capital simbólico, cujo dispositivo central e o mercado matrimonial, que estão na base de toda a ordem social: as mulheres só podem aí ser vistas como objetos, ou melhor, como símbolos cujo sentido se constitui fora delas e cuja função é contribuir para a perpetuação ou o aumento do capital simbólico em poder dos homens. Verdade do estatuto conferido às mulheres que se revela a contrario na situação limite em que, para evitar o aniquilamento da linhagem, uma família sem descendentes do sexo masculino não tem outro recurso a não ser o de tomar para sua filha um homem (BOURDIEU, 2002, p.55-56)
\end{abstract}

Por muito tempo a mulher foi tratada desta forma, também na sociedade brasileira, que tem em suas raízes a cultura patriarcal. Pode-se dizer que em algumas situações, ainda nos dias atuais a mulher toma status de objeto. Isto explica a revolta de "Seu" Noronha, por suas filhas não terem se casado, e o fato de toda a família acabar depositando suas últimas esperanças na filha caçula Silene, que era virgem, e deveria salvar a honra da família casandose. A castidade de Silene, de acordo com as reflexões de Bordieu (2002), representava seu 
valor simbólico para a troca matrimonial; destituída sua honra, não teria mais possibilidades de um bom casamento, restando-lhe somente a prostituição.

A cena citada acima, que conta a reação de todos ao saberem da gravidez de Silene, revela uma situação de dependência entre os personagens, mais complexa do que possa aparentar em uma primeira leitura. Como se não bastasse não ter a família ideal e não conseguir mudar isto, "Seu" Noronha não é o chefe ideal, não cumpre o papel de proteger e perdoar, como o próprio personagem do Dr. Bordalo sugere anteriormente. Oferece as filhas a prostituição, o que enfatiza o status de objeto conferido às mulheres. Mas quem constitui quem? Noronha se constitui desta maneira por causa da família que tem, ou sua família se comporta assim porque Noronha não é um bom chefe, tentando resolver as situações da forma mais torta possível, aos olhos da sociedade. Na cena constata-se que um depende do outro, são escravos uns dos outros, pois a esposa e as filhas aceitam a dominação do pai e esposo.

Esta cena é uma das cenas mais tensas, e no filme esta tensão ganha muito mais proporção, deixando de lado o humor da chanchada para dar lugar ao clima de loucura descabida que justifica a tragédia.

Na cena está presente toda a família. O cenário sugere uma casa de família simples, com objetos tradicionais, um relógio em cima da cristaleira, um ventilador e um Pinguim em cima da geladeira rosa, quadros pela parede colaboram para a produção de um efeito de sentido de realidade e de um cotidiano da família suburbana carioca daquele tempo. Geladeira Rosa? Estamos falando de uma família só de filhas, um ambiente em que o único elemento masculino é o pai; culturalmente, na nossa sociedade, o rosa é uma cor associada ao feminino, cor da beleza, do romantismo do amor terno e carinhoso, estabelece uma contradição com a cena em analise, o rosa é o vermelho suavizado com o branco. Os figurinos são simples também. Silene conserva o uniforme do colégio, a famosa combinação de camisa branca com a saia azul frisada - até nos dias de hoje remete a figura da colegial, que não deixa de ter uma conotação erótica. As demais mulheres usam vestidos simples, mas não dispensam o decote, "Seu” Noronha traja calça cinza e camisa branca, Dr. Bordalo como o bom médico está todo de branco.

Durante a cena cresce o som de uma música, tocada mais alto no momento também "alto" da cena, o momento em que Dr. Bordalo indaga às mulheres sobre o porquê de permanecerem na casa, a mercê de um pai de família de certa forma desequilibrado. A música trata-se da Valsa das Flores, composta por Tchaicovisky, que faz parte do espetáculo $O$ Quebra Nozes, justificada pela presença da TV que exibe naquele momento cenas do 
espetáculo de Ballet. O quebra Nozes é um Ballet de repertório que conta o episódio em que a garotinha Clara ganha um boneco quebra nozes, presente de seu padrinho Herr Drosselmeyer, que divertia as crianças com mágicas e brincadeiras durante a festa de natal. No fim da festa, depois que todos já estão dormindo, Clara volta para a sala e adormece ao lado da árvore de natal e de seu presente. Clara sonha que um exército de ratos está invadindo sua casa, mas $\mathrm{O}$ Quebra Nozes a defende comandando um exército de soldadinhos de chumbo. O Rei dos ratos acaba ferindo o Quebra Nozes, Clara o salva atirando seu sapato nos ratos. O padrinho de Clara aparece e transforma o Quebra Nozes em um príncipe que a leva ao reino das neves e ao reino dos doces, a fada açucarada, rainha do reino dos doces, homenageia Clara com uma grande festa, onde todos os habitantes do reino dançam, representando as várias regiões, podem ser as danças do chinês, árabe, russos, etc, e é após estas apresentações que se tem a Valsa das Flores, momento em que Clara dança com o príncipe, ponto alto e emocionante do espetáculo.

$\mathrm{Na}$ cena em análise do filme, no momento em que Dr. Bordalo indaga às personagens: "E vocês? Não dizem nada? Não reagem?” enquanto Dr. Bordalo continua argumentando, a câmera faz movimento panorâmico mostrando os rostos das personagens, como que perguntando a cada uma delas: não vão reagir? E realmente a expressão é de nenhuma reação contrária ao que o chefe da família propõe, mesmo Aurora que tentou protestar, mas seu protesto não tem força contrária, uma vez que se oferece para ir no lugar da irmã caçula. Desta maneira a materialidade fílmica conduz o expectador a evidenciar o paradoxo estabelecido pelas aparências da família Noronha, a TV neste momento não provoca apenas um efeito de sentido de realidade, como também propõe uma reflexão crítica ao comportamento da personagem que representa o pai de família. Um pai de família só de filhas, que deveria assegurar a integridade delas, filhas que deveriam, como todas as filhas bem nascidas, estar sonhando com o príncipe encantado, assim como a Clara de O quebra nozes, que deviam estar vivendo este sonho, o de encontrar o bom partido, o sonho do bom casamento. Nem mesmo Silene, a única da família que foi lhe permitido sonhar desta forma, ou mesmo a família sonhou por ela, não obedece esta ordem natural. Tudo falhou com Silene também, cuja família desejava que fosse pura, desejavam que pelo menos com ela o "adestramento" imposto pela sociedade desse certo. Se na TV as coisas davam muito certo, de acordo com o que se espera das meninas puras, na casa de Noronha se dava o contrário, é o próprio pai que empurra agora todas as filhas para a prostituição, até mesmo Silene, que havia descoberto estar grávida, fato este que, decisivamente, deflagra o fim do sonho da princesa. 
A música clássica não combina com a gravidade da cena, produz um sentido grotesco, insano, a figura do pai aqui é representada de forma perversa longe do que se espera ser normal. Ao assistirmos tal cena, observamos que esta não pretende deslocar os sentidos produzidos na materialidade do texto teatral, e sim enfatizá-los. A materialidade fílmica vai guiando o expectador por meio das estratégias que lhe estão à disposição e que lhes são próprias. No filme temos o personagem constituído imageticamente, acompanhado de cenário e som, um justificando o outro, produzindo um efeito de sentido de realidade. Neste caso a trilha sonora chega para contribuir para a produção dos sentidos que o diretor pretende organizar.

A materialidade fílmica não está presa somente às palavras; é uma composição de imagem, neste caso, é por meio da imagem que Neville D’ Almeida re-significa o discurso de Nelson, por meio de elementos como o olhar da câmera, figurinos, cenários e sons que estabelece novas relações capazes de produzir novos sentidos e enfatizarem sentidos já antes produzidos. Devemos considerar que o processo em que resulta a materialidade fílmica revela diversas posições sujeito, cada uma desempenhando uma função diferente, pois um filme se compõe coletivamente: atores, figurinistas, cenógrafos e sonoplastas envolvidos, ao comando do diretor que por sua vez assume a função de organizar tudo isto, como dito anteriormente, a função de organizar os sentidos, a função de autor.

A segunda cena que chamamos a atenção para este trabalho é o final da peça, a morte de "Seu" Noronha, logo após este ter matado Bibelot:

HILDA (histérica também) - Papai! Não é o homem que chora por um olho só!

ARLETE (crescendo para o pai) - Assassino!

(As filhas avançam para o pai, que recua.)

"SEU" NORONHA (já apertado pelo medo) - Mas ele merecia morrer, porque prostituiu Silene!

ARLETE (histérica) - Mentira! Quem prostituiu Silene foi você!

"SEU" NORONHA - Juro!

ARELETE (agarrando-o) - Mandou o gringo e, depois, o médico! (para as outras) Vocês! Ouçam o que eu nunca disse, o que eu escondia para mim mesma. (Violenta, para o pai) Velho! Você mandou um deputado me procurar!

"SEU” NORONHA (DESESPERADO) - Não acreditem!

ARLETE - O deputado me disse: "foi seu pai"...

"SEU" NORONHA - (NUM APELO PARA D. Aracy) - gorda, minhas filhas querem me destruir!

D. ARACY - (fora de si) - Não me chame de Gorda! Não quero que me chamem de Gorda!

ARLETE - (berrando) - Responde: eras tu que mandava os velhos para as outras?

DÉBORA - É verdade, papai?

ARTELE - Confessa, velho!

"SEU" NORONHA (apavorado) - Eu explico!

ARLETE (cega de ódio) - Fala!

"SEU" NORONHA (apavorado) - Eu explico!

ARLETE (cega de ódio) - Fala! 
"SEU" NORONHA (ofegante) - Eu fiz isso porque...E vocês se prostituíam para dar a Silene um casamento de anjo...(num repente feroz) E, além disso, você, (olha para Arlete e, depois, para as outras) ela beija mulher na boca!

ARLETE - Beijo mulher na boca para me sentir menos prostituta!

"SEU" NORONHA - (novamente acobardado) - Perdão!

ARLETE (violenta) - Velho! Prostituíste tuas filhas e não choras? Não chora por nós e por ti? Chora, velho!

"SEU” NORONHA - Estou chorando.

ARLETE (apertando o rosto do pai entre as mãos) - Deixa eu ver tua lágrima ... (lenta e maravilhada) Uma lágrima, uma única lágrima ... (num berro triunfante) Velho! Você é o demônio que chora pó um olho só! Dá o punhal, velho! Esse punhal! Dá!

ARLETE (feroz, erguendo o punhal) O punhal no olhar da lágrima!

HILDA (berrando) - Larguem o meu pai! Assassinas!

(E, súbito, Hilda cai em transe mediúnico. Recebe o primo Alípio.)

HILDA (com voz de homem) - Mata, sim, mata e enterra o velho e a lágrima no quintal! Velho safado!

FIM DO TERCEIRO E ÚLTIMO ATO (RODRIGUES, 2004, p. 187-188)

Nesta cena em que Silene não participa, no filme, como já mencionado, a mediunidade de Hilda não é explorada. Nesta cena esta mediunidade dá lugar a um outro tipo de ritual. As mulheres usam figurinos em tons de vermelho, sem dispensar o decote, a camisa de "Seu" Noronha também é vermelha, aberta sobre uma outra branca, para destacar o sangue da apunhalada. As filhas colocam o pai sobre a mesa, e é Arlete que lhe crava o punhal no peito. O cenário é a sala de jantar da família novamente, que não possui parede que a separe da sala de estar. Depois da apunhalada elas dão continuidade a uma espécie de ritual satânico, gritam, dão gargalhadas, não se sabe se de prazer ou de dor, deixam os seios a mostra, colocam sobre o corpo flores de plástico que faziam parte da decoração e um retrato de criança, provavelmente de uma das filhas, talvez um retrato de Silene, que não participa da cena, e por outro lado, para a família Noronha, ela é o membro da família responsável pelo desencadear dos acontecimentos. O ritual acontece com uma música ao fundo que produz o sentido de suspense.

Este ritual nos reporta aos rituais ao deus Dionísio, deus do vinho, das festas, da insânia e da intoxicação (Baco na fé Romana), praticados na Grécia antiga por mulheres, conhecidas como bacantes. Estas mulheres mostram-se intoxicadas e violentas, como na ocasião em que despedaçam Penteu rei de Tebas, na tragédia de Eurípedes (2012) As Bacantes.

Como se não bastasse esta expansão na cena Neville D’ Almeida não para por ai. Ele termina o filme mostrando a concretização da idéia de "Seu" Noronha, de transformar a casa da família em um bordel de filhas. Na cena final, com música carnavalesca, D. Aracy apresenta suas filhas, inclusive Silene, grávida, e inicia a "função" com muita dança, retornando ao clima de chanchada. 
Mas este final é muito mais que isto, vem confirmar nossa reflexão sobre o sujeito. As afirmações de Lacan de que o sujeito é antes de tudo falado pelo outro, fruto do discurso do outro, neste caso as filhas, não conseguem fugir ao destino, fruto do desejo do pai. Conforme o seguinte:

As opiniões e desejos de outras pessoas fluem para dentro de nós através do discurso. Nesse sentido, podemos interpretar o enunciado de Lacan de que o inconsciente é o discurso do Outro, de uma maneira muito direta: o inconsciente está repleto da fala de outras pessoas, das conversas de outras pessoas, e dos objetivos, aspirações e fantasias de outras pessoas (na medida em que estes são expressos em palavras). (FINK, 1998, p. 27)

O discurso do Outro é capaz de influenciar as capacidades do sujeito em desenvolver atividades. Isto era também observado por Bordieu, ao tratar da mudança de sexo, como algo que favorece uma "impotência apreendida", conforme vemos abaixo:

Quanto mais eu era tratada como uma mulher, mais eu me tornava mulher. Eu me adaptava, com maior ou menor boa vontade. Se acreditavam que eu era incapaz de dar marcha ré, ou de abrir garrafas, eu sentia, estranhamente, que me tornava incompetente para tal. Se achavam que uma mala era muito pesada para mim, inexplicavelmente, eu também achava que sim (MORRIS apud BOURDIEU, 2002, p.77)

Podemos dizer, a partir de então, que o discurso a respeito do sujeito tem grande influência na constituição do mesmo, e acabamos nos tornando, no discurso do outro, o que o Outro diz que somos.

\section{Conclusão}

Por meio destas breves reflexões, que de maneira nenhuma esgota as possíveis análises a respeito das posições sujeito, e muito menos das aproximações ou distanciamentos na produção de sentidos que a materialidade fílmica de Os Sete Gatinhos, dirigida por Neville D' Almeida pode produzir em relação à materialidade teatral em seu texto fonte, escrito por Nelson Rodrigues, podemos traçar algumas conclusões.

Tratamos aqui as personagens de ficção como instancias discursivas que produzem o efeito de realidade, de acordo com o que aquele que se propõe a organizar os sentidos de determinado texto toma como realidade, diante do que o mundo lhe oferece, deixando indícios de autoria, que refletem as escolhas das estratégias de produção, as quais deflagrarão as marcas autorais. E mesmo que tais escolhas sejam conscientes, o autor, tomado aqui como 
uma função sujeito, não tem controle sobre as opções de estratégias que lhe são oferecidas, as quais dependem da formação discursiva ${ }^{4}$ na qual se inscreve.

Pode-se observar que ao se propor a direção de um filme baseado no texto teatral de Nelson Rodrigues, Neville D' Ameida passa a partir de uma interpretação da materialidade teatral a re-significar o discurso rodriguiano, estabelecendo relações com outros dizeres, como a história de O Quebra Nozes e as Bacantes de Eurípedes, utilizando-se de estratégias possíveis para a constituição da materialidade fílmica, como observado nas duas cenas analisadas anteriormente, posicionando-se enquanto autor ao deslocar passagens da trama.

Concluímos também que, no caso das personagens principais da narrativa em questão, a Família Noronha, tanto na materialidade teatral como na materialidade fílmica, as posições sujeito das filhas e da esposa, dependem do discurso do pai, e este por sua vez também depende delas. Porém a relação entre eles, mediante os conceitos cristalizados por uma sociedade androcêntrica, de acordo com as reflexões de Bordieu (2002), é de sujeito e objeto, "Seu" Noronha é o sujeito dominador, chefe absoluto da família, sua esposa e filhas lhe devem obediência assumindo o status de objetos.

Podemos observar também, que a materialidade fílmica, por meio de estratégias próprias de sua produção, como cenário e sonoplastia, pode enfatizar os sentidos produzidos na materialidade do texto teatral, bem como deslocá-los ou expandi-los, visto que os dizeres passam por uma adequação ao gênero cinematográfico conforme tendências da época. Á medida que acrescenta cenas que no texto teatral são somente relatadas, e reelabora cenas, pois o discurso cinematográfico não está preso somente às palavras como o discurso do texto teatral, pode recorrer a outras estratégias considerando-se que se manifesta por meio da composição de imagens. No caso de nossos objetos de análise - teatro e cinema-, o teatro vai ao cinema para ser re-significado, dando mais espaço ao erotismo, de acordo com as tendências da produção cinematográfica do final dos anos 70 e ao ser re-significado produz novos sentidos e sentidos outros.

\section{Referências}

\footnotetext{
${ }^{4}$ Para Pêcheux, as palavras, expressões, proposições, etc., adquirem sentido de acordo com as formações ideológicas nas quais as posições daqueles que as empregam se inscrevem. Formação discursiva "é aquilo que, numa formação ideológica dada, isto é, a partir de uma posição dada numa conjuntura dada, determinada pelo estado da luta de classes, determina o que pode e deve ser dito" (PECHEUX, 1997, p.160)
} 
BERDTICHEVSKY, Sura. Entrevista com Sura Berditchevsky. Disponível em: $<$ www.nelsonrodrigues.com.br/site/eobrenelson det.php?Id=3>. Acesso em: 07 jan. 2013;

BORDIEU, Pierre. A dominação Masculina. 2. Ed. Rio de Janeiro: Bertrand Brasil, 2002;

BRAIT, Beth. A Personagem. São Paulo: Ática, 1985;

COELHO, Frederico. Mangue Bangue. Disponível em:

$<$ http://objetosimobjetonao.blogspot.com.br/2009/07/mangue-bangue.html $>$ Acesso em: 23 abr. 2012.

DIEGUES, Carlos. Cinema Brasileiro - Idéias e Imagens. 1. ed., Porto Alegre: Ed. da Universidade / UFRGS, 1988;

EDWALD FILHO, Rubens. Nelson Rodrigues mal captado. Disponível em:

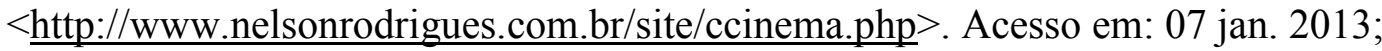

EURÍPEDES, As Bacantes, disponível em:

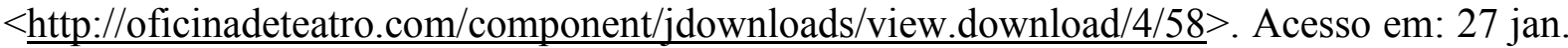
2012.

FINK, Bruce. O Sujeito Lacaniano - Entre a Linguagem e o Gozo. Rio de Janeiro: Jorge Zahar Ed., 1998.

GARDNIER, Ruy. Os Sete Gatinhos. disponível em $<$ http://www.portalbrasileirodecinema.com.br/nelson/obra\%20adaptada/cinema/02_01_12.ph p $>$ - acesso em: 02 set. 2010;

MAGALHÃES, Belmira. O Sujeito do Discurso: Um diálogo possível e necessário. In Linguagem em (Dis)curso, Tubarão, v. 3, Numero Especial, p. 73-90, 2003.

ORLANDI, Eni Puccinelli. Análise de Discurso - Princípios \& Procedimentos. 7. Ed, Campinas, São Paulo: Pontes, 2007;

OS SETE GATINHOS, Direção: Neville D'Almeida; Produtora: Cineville, Embrafilme e Terra Filmes; Produção: Scarlett Moon de Chevalier; Roteiro: Gilberto Loureiro e Neville D'Almeida; Fotografia: Edson Santos; Montagem: Marco Antonio Cury; Música: Lulu Santos, A Cor do Som; Intérpretes: Lima Duarte, Cristina Aché, Regina Casé, Thelma Reston, Ary Fontoura, Sura Berditchevsky, Antônio Fagundes; Rio de Janeiro, 1980, cor, 35 mm., 109 $\min$.

PÊCHEUX, Michel. Semântica e discurso: uma crítica à afirmação do óbvio. Campinas, SP: Editora da UNICAMP, 1997

REIS, Moura. Um Nelson Rodrigues Folhetinesco por inteiro. Isto é importante? Disponível em: $<$ http://www.nelsonrodrigues.com.br/site/ccinema.php $>$. Acesso em: 07 jan. 2013.

RODRIGUES, Nelson. Teatro completo. v. 3, 2. ed., Rio de Janeiro: Nova Fronteira, 2004. 
XAVIER, Ismail. $O$ discurso cinematográfico - A opacidade e a transparência. 4. Ed. São Paulo: Paz e Terra, 2008.

[Recebido em julho de 2012 e aceito para publicação em dezembro de 2012]

The Theater goes to the cinema: position subject

Abstract: This article aims to analyze the play "The Seven Kittens" (Os Sete Gatinhos), written in 1958 by the Brazilian playwright Nelson Rodrigues and its adaptation for the cinema, homonymous, direct by Neville D' Almeida, launched in 1980. The theoretical approach which will serve as the basis for the above analysis will be the Anlysis of the Discourse of French oriented, as well as other theories that will help, as the reflections about lacanian subject by Bruce Fink (1998) and film studies by Ismail Xavier (2008). Fruit of the basic research of bibliographical and interpretative, this paper aims to present reflections about subject positions, devoting attention to the characters from the materiality of theatrical text, noting whether these positions are displaced in the filmic materiality. It will be verified beyond this possibility of subject positions, the inclusion or withdrawals of dialogues, the senses preserved, removed or added by means of elements that compose the whole of film production such as music, scenery, costumes, constitution of the image by means of the movement of the câmera (first and second plans, focus, etc.), strategies aimed at the production of meanings by following the trends of the cinema of the years 70/80. This reflection is done while considering the materiality of the film is the result of a collective productions, led by a director, with different responsible for photography, set design, editing and soundtrack, as well as intervention in the creation of characters by each actor.

Keywords: Speech. Position subject. Materiality theater. Filmic materiality. Production of meanings

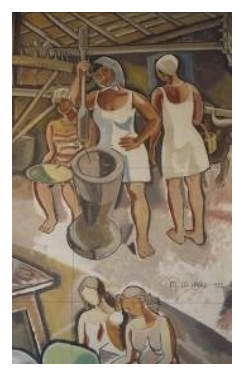

